\title{
Study of Greenhouse Use of Biohazard Wastewater and Manure Compost
}

\author{
ELENA GOLDAN ${ }^{1}$, VALENTIN NEDEFF ${ }^{1,2 *}$, IOAN GABRIEL SANDU ${ }^{3,4}{ }^{2}$, EMILIAN MOSNEGUTU ${ }^{1}$, MIRELA PANAINTE ${ }^{1}$ \\ ${ }^{1}$ Vasile Alecsandri University of Bacau, Faculty of Engineering, 157 Marasesti Str., 600115 Bacau, Romania \\ ${ }^{2}$ Gheorghe Ionescu Sisesti Academy of Agricultural an Forest Sciences, 61 Marasti Str., 011464, Bucharest, Romania \\ ${ }^{3}$ Gheorghe Asachi Technical University of Iasi, Faculty of Materials Science \& Engineering 61A D. Mangeron Blvd, 700050, Iasi, \\ Romania \\ ${ }^{4}$ Romanian Inventors Forum, 3 Sf Petru Movila, St. BI L11, Sc A, Et III, Ap 3, 700089, Iasi, Romania
}

\begin{abstract}
The biochar used on agricultural land, can have a wide range of physical, chemical and biological effects on soil properties. Also cattle manure is important notonly as the amount of nutrients inserted into the soil, but also for improving the conditions for growth and development of the plants. The positive effects on soil properties and plant growth are usually observed when biochar is used in mixture with other types of organic fertilizers. In this study, was used sewage sludge biochar, cattle manure compost, and mixtures made from these organic wastes in different concentrations, at application rates of 5 t/ha and 30 t/ha, with the aim of to determine the effects on soil properties and barley plants. The use of biochar, compost and biochar-compost mixtures at 30 t/ha, produced a significant increase of barley plants and an improvement of the $\mathrm{pH}$, electrical conductivity and soil respiration, while at 5 tha application rate, the effect of this two organic wastes and mixtures of these in different concentrations, on plants growth and soil was reduced.
\end{abstract}

Keywords: sewage sludge biochar, manure compost, soil, plants

Sewage sludge and manure are two of the most abundant wastes and can represent an important source of nutrients for soil and plants growth, and from this reason, this wastes can be used as fertilizer in agriculture [1].

The sewage sludge is rich in nutrients, organic matter and trace elements that are beneficial for plant growth and soil fertility, but also, the sludge contains chemical pollutants, heavy metals, pesticides, pathogens and other dangerous organic compounds which can be released into the environment [2-6]. Sludge resulting from wastewater treatment can create significant environmental problems related to air emissions, soil and water resources contamination, so this waste requires proper treatment and efficient management [7]. To attenuate the negative effects of direct application of sewage sludge on agricultural land, its transformation into biochar by the pyrolysis process constitutes an efficient method of recycling this waste [8]. The pyrolysis process significantly reduces the weight and volume of the sludge, the heavy metals are immobilized and their bioavailability in soil is reduced, pathogens and unpleasant smell are removed, resulting a solid product that has a positive impact on the soil properties and also on plant growth [8-10].

The manure from cattle is considered an organic waste that is found in large quantities and is widely used on agricultural fields [11]. Cattle manure was extensively used as an organic fertilizer because it has a high content of nitrogen, phosphorus and potassium [12]. Composting is considered an efficient method to transform manure into a stabilized, disinfected and useful product for agriculture, and studies on this topic have increased in recent years [13]. Utilisation of compost for soil fertilization is associated with minimizing the risk of spreading pathogens, weeds and improving the quality and soil fertility, and also increase production and quality of the crops [14, 15].

The sewage sludge biochar has lower nitrogen content and because of this is recommended to be use it in mixture with other types of organic fertilizers to improves soil properties and to provides essential nutrients for plants [16] .

\footnotetext{
* email: vnedeff@ub.ro; Phone: +40723675128
}

The biochar-compost mixture can improve crop yields through a variety of mechanisms, including increasing the amount of nutrients, soil $\mathrm{pH}$ improvement, improved nutrient efficiency and therefore nutrient uptake by plants and improved water retention capacity in the soil [17]. The use of biochar in mixtures with compost obtained from various organic wastes was proposed as a method of improving, physical, chemical and biological properties of the soil and crops productivity and can be considered a solution for remediation of degraded soils [18].

The aim of the study is to determine the influence of sewage sludge biochar, cattle manure compost, and mixtures made from this organic wastes in different concentrations, at two application rates on the autumn barley plants and soil properties.

\section{Experimental part \\ Soil and feedstock}

The soil used in the study was collected from an uncultivated area by at least 5 years from Bacãu county, Romania in J uly 2016. The soil was air-dried, passed through a sieve with holes of $4 \mathrm{~mm}$ and homogenized before to start the greenhouse experiment.

The sewage sludge biochar was provided by the NovoCarbo Company from Germany and was obtained by slow pyrolysis at $500^{\circ} \mathrm{C}$ and an retention time by 15 minute.

Cattle manure compost was obtained after a traditional method used in Romania to produce compost. The manure was placed in a pile on the soil surface and covered with a layer of soil by approximately $15-20 \mathrm{~cm}$ thick and left in natural conditions for approximate 2 years. After this period, the soil layer was removed and was collected the traditional Romanian compost, named mrania, which was, air-dried, then passed through a sieve with $4 \mathrm{~mm}$ holes and was again air-dried until has reached constant weight.

\section{Greenhouse experiment}

The greenhouse experiment was carried out between august-november 2016, in Bacau, Romania, for a period of 90 days, having as a study plant the autumn barley. 
The sewage sludge biochar and cattle manure compost was used in mixture with soil at two application rates by 5 t/ha and 30 t/ha. For each application rate, were used one control variant and 11 different concentrations.

The cattle manure compost (M) was used in concentrations by: $0 \%, 10 \%, 20 \%, 30 \%, 40 \%, 50 \%, 60 \%$, $70 \%, 80 \%, 90 \%, 100 \%$ in mixture with sewage sludge biochar (B) in concentrations by: $100 \%, 90 \%, 80 \%, 70 \%$, $60 \%, 50 \%, 40 \%, 30 \%, 20 \%, 10 \%, 0 \%$. For each treatment, 6 replicate was used, each having a weight of $1.5 \mathrm{~kg}$.

The treatments were named according to the rate of application and the concentrations used: $\mathrm{C}$ (control), $\mathrm{MO}$ B100, M10-B90, M20-B80, M30-B70, M40-B60, M50-B50, M60-B40, M70-B30, M80-B20, M90-B10, M100-B0

\section{Plant growth and dry biomass}

A number of 25 seeds of autumn barley were sown in each pot, and the number of germinated plants was counted and recorded daily. When plants had at least 2 leaf formats, the number of barley plants, was reduced at 2 plants in each plastic container. Determination of barley plant height and number of tillers was performed in the middle ( 44 days) and end of greenhouse experiment ( 88 days). After 90 days, barley plants were cut from the soil surface and dried at $70^{\circ} \mathrm{C}$ for 12 hours, and was determined the dry biomass of the plants $[19,20]$.

\section{Analysis of soil samples}

The soil samples were taken with a metal cylinder of 15 $\mathrm{cm}$ height and $4 \mathrm{~cm}$ diameter. The samples were air-dried and stored.

To measure the $\mathrm{pH}$ and electrical conductivity of the soil, aqueous suspensions were made in a ratio of 1:5 soil:distilled water, which was homogenized for 2 hours at $120 \mathrm{rpm}$ and filtered before the measurements began. This method for measuring $\mathrm{pH}$ and soil conductivity has been used similarly in other studies [21, 22].

The Hydrochloric acid titration method was used to measure soil respiration. Inside of the glass bottle was put wetted soil and another container with sodium hydroxide solution, the glass bottle was sealed hermetically and left for 24 hours at $20^{\circ} \mathrm{C}$. After incubation, the container with sodium hydroxide solution was taken and was added barium chloride solution and few drops of phenolphthalein and the colour became pink. The solution was titrated with hydrochloric acid solution until the colour becomes whitish again $[23,24]$.

\section{Results and discussions}

\section{Plant germination}

The barley, (Hordeum vulgare L.) is a plant that is resistant to stress conditions and is the fourth most important crop in the world, after wheat, maize and rice, mainly used in the food industry and for animal food [2528].

From figures 1 and 2 , it can be noticed that at 5 tha and $30 \mathrm{t} / \mathrm{ha}$, application rate of the sewage sludge biochar,

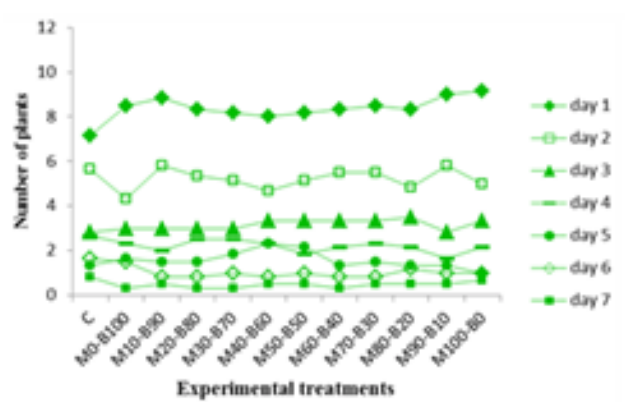

Fig. 1. Barley plants germinated at 5 t/ha application rate

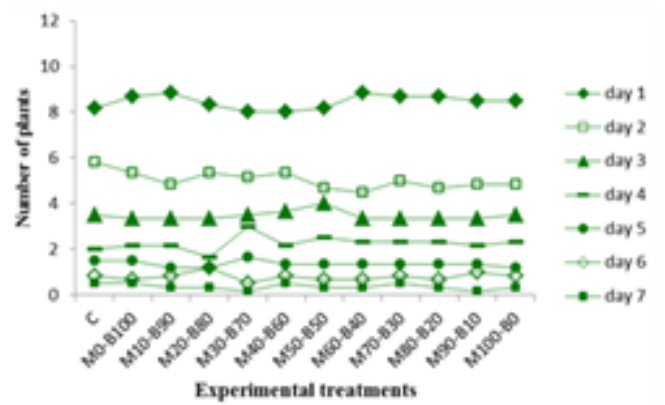

Fig. 2. Barley plants germinated at 30 tha application rate

cattle manure compost and mixtures sewage sludge biochar-cattle manure compost, many plants germinated in the first 2 days, after the number of germinated plants has decreased until in day 7 , when was recorded the lowest values of germinated plants.

In comparasion with soil control can be observed from figure 1. that the sewage sludge biochar and cattle manure compost, didn't influenced germination of the barley plants. When the germination period ended, the germinated barley plants were removed, leaving only two barley plants in each plastic container.

\section{Barley height}

The positive effect of mixtures sewage sludge biocharcattle manure compost on barley plant growth, is very noticeable at the application rate of $30 \mathrm{t} / \mathrm{ha}$, where the barley plant height has reached the highest values especially in treatments with a high concentration of cattle manure compost.

The height of the barley plants measured at 5 t/ha application rate of mixtures sew age sludge biochar- cattle manure compost, did not vary greatly compared to the barley plants height measured in the control variant, only in treatments with $100 \%$ cattle manure compost - $0 \%$ sewage sludge biochar (M100-B0) and 90\% cattle manure compost - 10\% sewage sludge biochar (M100-B0), a significant increase in barley plant height is observed both after 44 days and 88 days after sowing (figs. 3 and 4).

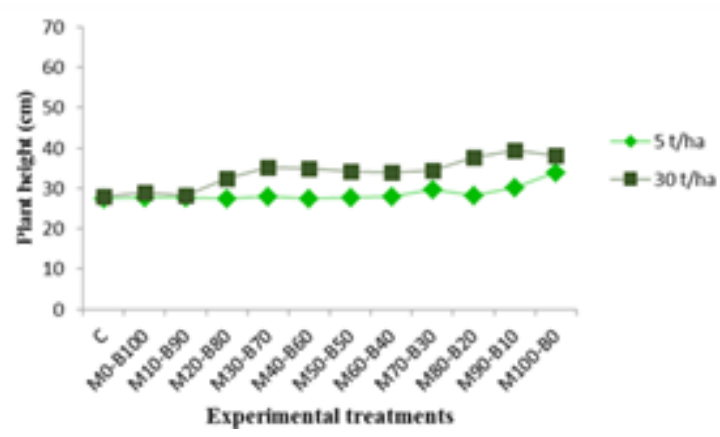

Fig. 3. The barley plants height at 44 days after sowing

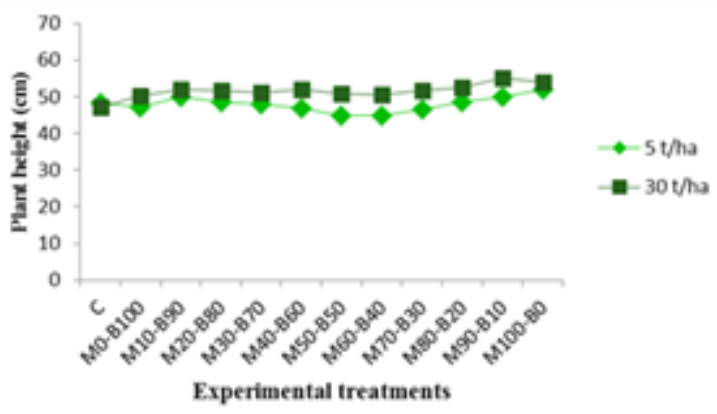

Fig. 4. The barley plants height at 88 days after sowing 
From figure 3, can be observed that treatments with a high concentration of sewage sludge biochar in mixture with a low concentration of cattle manure compost, had a lower effect on the growth of plants at $5 \mathrm{t} / \mathrm{ha}$ and also at 30 t/ha application rate in comparison with plants height obtained in treatments with a small concentration of sewage sludge biochar in mixture with a high concentration of cattle manure compost.

Results obtained after utilisation of manure compost and sewage sludge biochar on plant growth have been reported in other studies. For example, the growth of spinach plants has been improved by the application of compost from cattle manure due to the high content of organic matter and nutrients [29].

In another study, it has been observed that after application of the sewage sludge biochar, increased the height of the tomato plants, the dry biomass and the number of fruits obtained [20]. Compared to the results obtained in the control variant, maize growing and biomass production was improved in treatments where sewage sludge biochar was used [16].

\section{Tillers number}

The number of tillers determined in the middle and at the end of the greenhouse experiment increased in all mixtures sewage sludge biochar- cattle manure compost, used in different concentrations at the two application rates.

Figure 5 shows that the number of barley tillers at 5 t/ha and at 30 t/ha application rate, increased in all the experimental treatments, especially at the application rate of $30 \mathrm{t} / \mathrm{ha}$ of sewage sludge biochar-cattle manure compost, where the number of barley tillers was significantly higher.

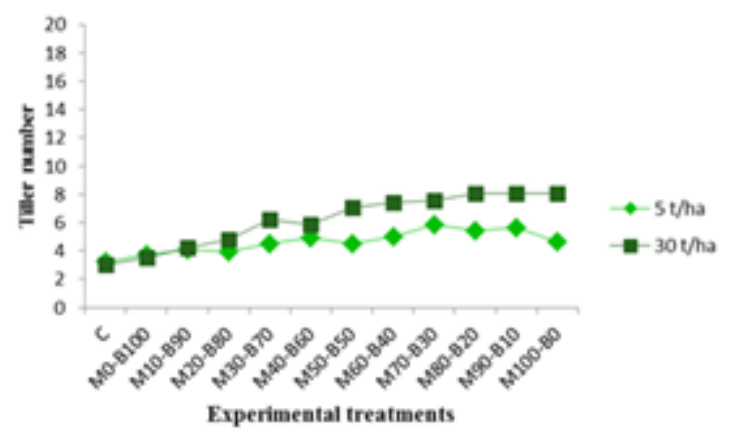

Fig. 5. Tillers number at 44 days after sowing

At the end of the greenhouse experiment, it appears from figure 6 , that the number of tillers almost doubled compared to their number determined in the middle period of the experiment. The effects of the cattle manure compost in comparasion with sewage sludge biochar on barley grothw, was more significant because the growth parameters of the plants measured in this experiment, recorded high value in treatments with cattle manure compost used in big concentration.

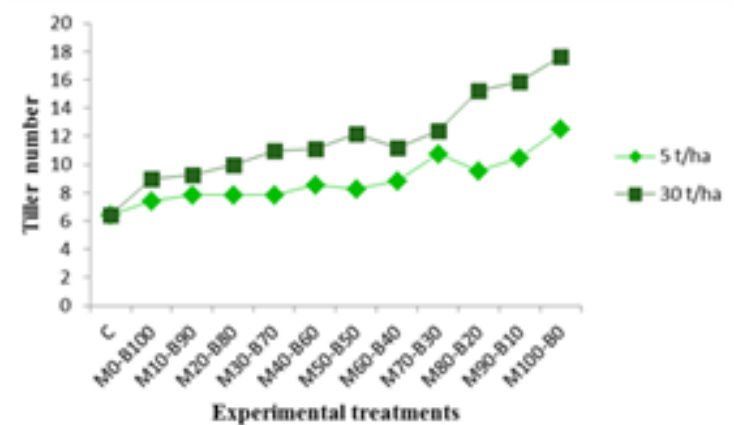

Fig. 6. Tillers number at 88 days after sowing
In a study, where cattle manure compost was used, the results show ed that onion plant height, the number of leaf and the diameter of the bulb onion, generally showed increasing values depending on the increase of application rates [30].

The height of the rice plants, the number of tillers, the amount of rice grains increased especially when the application rate of the sewage sludge biochar increased [31]. Growth parameters of French mallows showed significant differences due to the application of sewage sludge biochar compared to the control variant [32].

\section{Dry biomass of autumn barley plants}

At the end of the greenhouse experiment, it was observed that the use of cattle manure compost, the sewage sludge biochar and mixtures of these organic wastes in different concentrations, had a positive effect on the amount of dry biomass obtained.

Figure 7 shows the results from the barley plant dry weight, and it is noted that at the 5 t/ha application rate, was a slight increase of the dry weight of the barley plants compared to control variant, the most significant values were determined in mixtures with a high concentration of cattle manure compostin mixture with a low concentration of sewage sludge biochar.

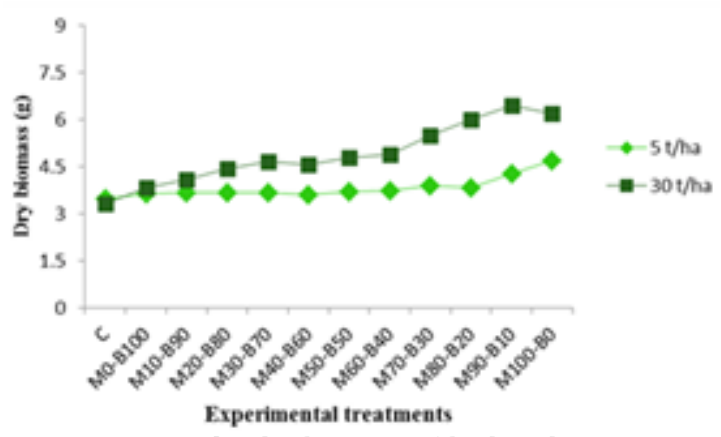

Fig. 7. The dry biomass of barley plants

The positive influence of the cattle manure compost on plant growth and productivity was demonstrated in other studies. For example, the total biomass of rice plants obtained at the end of the experiment was higher in treatments with cattle manure compost [33]. In another study, dried spinach biomass increased significantly after applying compost obtained from cattle manure and poplar leaves [34].

Also exist studies that report an improvement in plant growth following the application of sewage sludge biochar. The amount of biomass of salad plants increased in all samples modified with different application rate of sewage sludge biochar [35]. In another study, cucumber biomass was significantly higher in treatments with sewage sludge biochar [36].

Many studies have show $n$ that adding organic fertilizers to soil has multiple benefits on crop productivity and soil fertility, including improving soil structure and stimulating nutrient availability, resulting high yields of plants [37].

The use of cattle manure improves the physical properties of the soil, which promotes greater absorption of nutrients present in manure by plant roots and thus contributes to the growth of plants and their productivity [38].

Adding sewage sludge biochar in soil improves soil aeration, increases water retention capacity and nutrient content, creating favourable conditions for plant growth [20]. Growth of plant biomass after sewage sludge biochar was added in soil, has been attributed to the fact that the biochar contains significant amounts of nutrients needed for plant growth, such as K, Ca, Mg and P [16, 39]. 


\section{SoilpH}

At 5 tha application rate of sewage sludge biochar cattle manure compost, the soil $\mathrm{pH}$ did not increase significantly in treatments with a high concentration of sewage sludge biochar, but a slight increase in $\mathrm{pH}$ was observed, in mixtures with $100 \%$ cattle manure compost$0 \%$ sewage sludge biochar (M100-B0) and 90\% cattle manure compost-10\% sewage sludge biochar (M90-B10), as shown in figure 8.

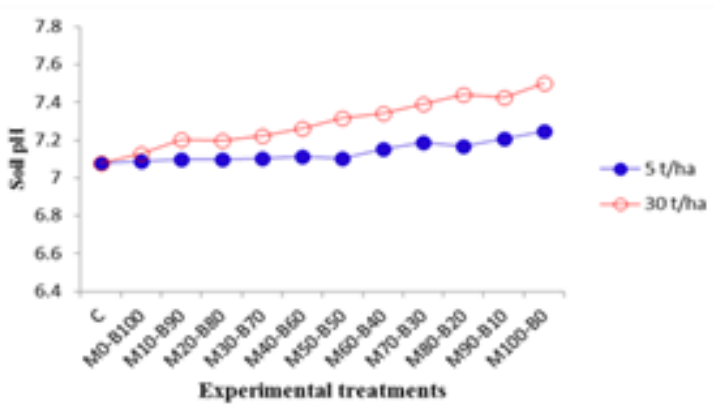

Fig. 8. Effects of mixtures biochar-compost on soil pH

When sewage sludge biochar-cattle manure compost was used at $30 \mathrm{t} / \mathrm{h}$ a application rates, the soil $\mathrm{pH}$ has been increasing, the highest values being in the treatments with high concentration of cattle manure compost. The increase of soil $\mathrm{pH}$ demonstrates that composting could be useful for increasing the $\mathrm{pH}$ of acidic soils and for avoid $\mathrm{pH}$ lowering after successive application of inorganic fertilizers [40].

The sewage sludge biochar produced at $500^{\circ} \mathrm{C}$, compared to the control variants, increased the $\mathrm{pH}$ of the soil for both application rates, but had a lower effect than cattle manure compost. An increase of the $\mathrm{pH}$ of the soil after application of the sewage sludge biochar is due to the alkaline $\mathrm{pH}$ of the biochar, which varies according to the production temperature and the type of raw material [41]. And another authors [31], have found that has been an increase in soil $\mathrm{pH}$ depending on the increase in the application rates of sewage sludge biochar.

Following the use of cattle manure compost, was an increase in soil pH and electric conductivity in the study conducted by [32]. Also, was a significant increase in soil $\mathrm{pH}$ due to the application of cattle manure compared to the control variant [33].

\section{Electrical conductivity of the soil}

Compared with the control variant, mixtures sewage sludge biochar- cattle manure compost increased the electrical conductivity of the soil. It can be observed from figure 9 , the difference between results obtained at application rates of $5 \mathrm{t} / \mathrm{ha}$ and $30 \mathrm{t} / \mathrm{h}$, the maximum value of the soil conductivity were registered at $30 \mathrm{t} / \mathrm{ha}$ application rate.

In the article [42], in which several types of biochar were used, including sewage sludge biochar, it was observed

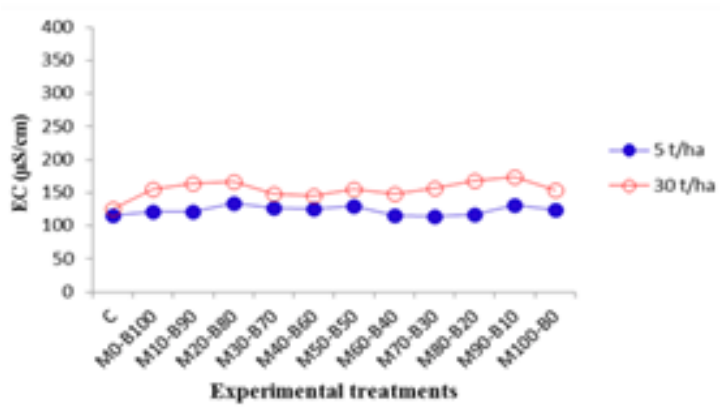

Fig. 9. Effects of mixtures biochar-compost on soil electrical conductivity that the $\mathrm{pH}$ and electrical conductivity of the soil increased with increasing application rates. Also other studies reported an increase in $\mathrm{pH}$ and soil electrical conductivity after utilisation of sewage sludge biochar $[43,44]$.

As a result of measurements of soil samples, it has been observed that application of cattle manure compost improved pH and electric conductivity of the soil [45]. From the results presented in another study, where was used compost from cattle manure in mixture with inorganic fertilizer, and inorganic fertilizer, it appears that the $\mathrm{pH}$ and the electrical conductivity of the soil increased significantly in the treatments with cattle manure compost [40]. The increase of the electrical conductivity of the soil can be attributed to a large amount of soluble cations in the compost and their release into the soil [34].

\section{Soil respiration}

Measurement of soil respiration is important for the assessment of the decomposition of organic matter, biomass and the microorganisms activity in soil [46]. Are several factors that influence soil respiration, such as: nature and composition of organic fertilizer, amount added in soil and nutrient content [47].

The effect of mixtures sewage sludge biochar- cattle manure compostat $5 \mathrm{t} / \mathrm{ha}$ application rate on soil respiration was almost insignificant for all experimental treatments. Only at 30 tha application rate, was observed an increase in soil respiration due to the application of this two organic wastes.

From figure 10, it is observed that mixtures with a high concentration of sewage sludge biochar, had a lower effect on soil respiration compared to mixtures with a high concentration of cattle manure compost.

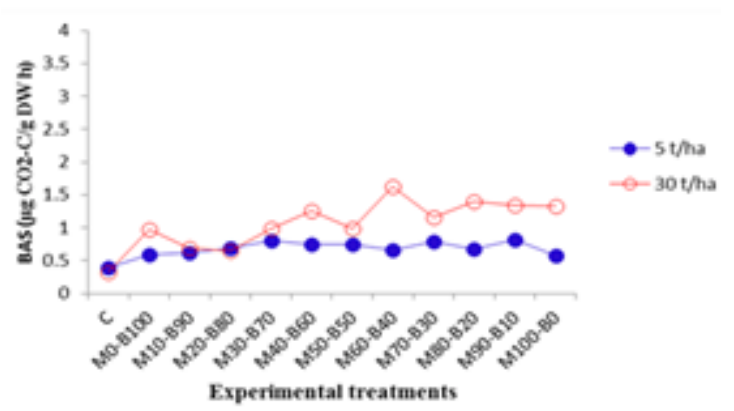

Fig. 10. Effects of mixtures biochar-compost on soil respiration

Increased soil respiration can be explained by mineralization of manure components, for example, organic matter soluble from manure contains sugars, amino sugars, amino acids, proteins and organic acids that decompose rapidly in soil [48].

The application rate and amount of biochar used in the experiment could be an important factor which influences soil respiration [49]. Previous studies have shown that microbial soil biomass and microbial activity have increased as a result of the increase in the amount of biochar in soil [50]. Also in the work [51], the addition of sewage sludge biochar increased the soil respiration soil compared to the control variant.

\section{Conclusions}

The growth of barley plants was positively influenced by the sewage sludge biochar, cattle manure compost and by the mixtures sewage sludge biochar - cattle manure compost, made in different concentration at 5 t/ha and 30 t/ha application rate. Barley plants recorded the most significant values at 30 t/ha application rate, especially in 
treatments with a high concentration of cattle manure compost.

After application of sewage sludge biochar-cattle manure compost mixtures at 30 t/ha application rate, a significant increase in soil $\mathrm{pH}$, conductivity and soil respiration was observed, especially in treatments with high concentration of cattle manure compost in mixture with a low concentration of sewage sludge biochar. A lower effect on soil $p H$, conductivity and soil respiration was recorded at application rate of $5 \mathrm{t} / \mathrm{ha}$, but compared with the control variant it was observed that the treatments with sewage sludge biochar in mixture with cattle manure compost improved soil properties also at this application rate.

Acknowledgements: The authors would like to thank NovoCarbo company from Germany for providing sewage sludge biochar used in the study.

\section{References}

1.RUIZ-GOMEZ, N., QUISPE, V., ABREGO, J., ATIENZA-MARTINEZ, M., MURILLO, M.B., GEA, G., Waste Manag, 59, 2017, p. 211.

2.HUANG, H.-J., YANG, T., LAl, F.-Y., WU, G.-Q., J ournal of Analytical and Applied Pyrolysis, 125, 2017, p. 61.

3.GOBERNA, M., SIMON, P., HERNANDEZ, M.T., GARCIA, C., Sci Total Environ, 615, 2018, p. 360.

4.J ANOW SKA, B., SZYMANSKI, K., SIDELKO, R., SIEBIELSKA, I., WALENDZIK, B., Environ Res, 156, 2017, p. 394.

5.JOSEPH S. MTSHALI, A. T.T., AMOS O. FADIRAN, Resources and Environment, 4, 2014, p. 190.

6.ILIE, L., MIHALACHE, M., SCAETEANU, G.V., MADJ AR, R.M., POPOVICI, D. R., Rev.Chim.(Bucharest), 69, no. 5, 2018, p. 1166.

7.SAMOLADA, M.C., ZABANIOTOU, A.A., Waste Manag, 34(2), 2014, p. 411.

8.NANSUBUGA, I., BANADDA, N., RONSSE, F., VERSTRAETE, W., RABAEY, K., Water Res, 81, 2015, p. 216.

9.WANG, H., FENG, M., ZHOU, F., HUANG, X., TSANG, D.C.W., ZHANG, W., Chemosphere, 184, 2017, p. 176.

10.LI, M., TANG, Y., REN, N., ZHANG, Z., CAO, Y., Journal of Cleaner Production, 172, 2018, p. 3342.

11.KIM, S.Y., PRAMANIK, P., GUTIERREZ, J., HWANG, H.Y., KIM, P.J ., Agriculture, Ecosystems \& Environment, 197, 2014, p. 60.

12.YUE, Y., LIN, Q., XU, Y., LI, G., ZHAO, X., Journal of Analytical and Applied Pyrolysis, 124, 2017, p. 355.

13.ZHAO, H.-Y., LI, J., LIU, J.-J., LÜ, Y.-C., WANG, X.-F., CUI, Z.-J., Journal of Integrative Agriculture, 12, no. 6, 2013, p. 1087.

14.ARRIAGA, H., VIGURIA, M., LOPEZ, D.M., MERINO, P., J Environ Manage, 2017, p. 557.

15.HARIADI, Y.C., NURHAYATI, A.Y., HARIYANI, P., Agriculture and Agricultural Science Procedia, 9, 2016, p. 118.

16.GWENZI, W., MUZAVA, M., MAPANDA, F., TAURO, T. P., J ournal of Integrative Agriculture, 15, no. 6, 2016, p. 1395.

17.AGEGNEHUA, G., SRIVASTAVAB, A.K., BIRDA, M. I., Applied Soil Ecology, 119, 2017, p. 156.

18.DAIRO, O.S., SOYELU, O.J., International J ournal of Conservation Science, 8, no. 3, 2017, p. 509.

19.LI, G., KHAN, S., IBRAHIM, M., SUN, T.R., TANG, J.F., COTNER, J.B., XU, Y.Y., J Hazard Mater, 348, 2018, p. 100.

20.HOSSAIN, M.K., STREZOV, V., NELSON, P.F., Pedosphere, 25, no. 5, 2015, p. 680.

21.MARKS, E. A. N., MATTANA, S., ALCAÑIZ, J.M., DOMENE, X., European Journal of Soil Biology, 60, 2014, p. 104.
22.ZHANG, R.-H., LI, Z.-G., LIU, X.-D., WANG, B.-C., ZHOU, G.-L., HUANG, X.-X., LIN, C.-F., WANG, A.-H., BROOKS, M., Ecological Engineering, 98, 2017, p. 183.

23.BOLTER, M., BLOEM, J., MEINERS, K., MOLLER, R., Biology and Fertility of Soils, 36, no. 4, 2002, p. 249.

24.YUAN, H., LU, T., WANG, Y., HUANG, H., CHEN, Y., Journal of Analytical and Applied Pyrolysis, 110, 2014, p. 277.

25.CIORNEA, E.T., DUMITRU, G., SANDU, I., Rev. Chim.(Bucharest), 69, no. 8, 2018, p. 2160.

26.MARECEK, V., MIKYSKA, A., HAMPEL, D., CEJ KA, P., NEUWIRTHOVA, J., MALACHOVA, A., CERKAL, R., J ournal of Cereal Science, 73, 2017, p. 40.

27.DANERI-CASTRO, S.N., SVENSSON, B., ROBERTS, T.H., Journal of Cereal Science, 70, 2016, p. 29.

28.MARINACCIO, F., REYNERI, A., BLANDINO, M., Field Crops Research, 170, 2015, p. 109.

29.XU, C.,MOU, B., HortScience, 51, np. 12, 2017, p. 1517-1523.

30.LEE, J., HortTechnology, 22, no. 6, 2012, p. 798.

31.ZHANG, Y., CHEN, T., LIAO, Y., REID, B.J ., CHI, H., HOU, Y., CAI, C., Environ Pollut, 216, 2016, p. 819.

32.J AYASINGHE, G.Y., ARACHCHI, I.D.L., TOKASHIKI, Y., Resources, Conservation and Recycling, 54, no. 12, 2010, p. 1412.

33.DAS, S., JEONG, S.T., DAS, S., KIM, P.J ., Front Microbiol, 8, 2017, p. 1702.

34.ANWAR, Z., IRSHAD, M., MAHMOOD, Q., HAFEEZ, F., BILAL, M., International Journal of Recycling of Organic Waste in Agriculture, 6, no. 1, 2017, p. 79.

35.KHAN, S., WANG, N., REID, B.J., FREDDO, A., CAI, C., Environ Pollut, 175, 2013, p. 64.

36.WAQAS, M., KHAN, S., QING, H., REID, B.J., CHAO, C., Chemosphere, 105, 2014, p. 53.

37.ZHANG, Y., LI, C., WANG, Y., HU, Y., CHRISTIE, P., ZHANG, J., LI, X., Soil and Tillage Research, 155, 2016, p. 85.

38.MOSEBI, P., TRUTER, W.F., MADAKADZE, I., Livestock Research for Rural Development, 27, 2015.

39.XU, X., ZHAO, Y., SIMA, J., ZHAO, L., MASEK, O., CAO, X., Bioresour Technol, 241, 2017, p. 887.

40.GIL, M. V., CARBALLO, M.T., CALVO, L.F., Waste Manag, 28(8), 2008, p. 1432.

41.GUL, S., WHALEN, J.K., THOMAS, B.W., SACHDEVA, V., DENG, H., Agriculture, Ecosystems and Environment, 206, 2015, p. 46.

42.PANEQUE, M., DE LA ROSA, J.M., FRANCO-NAVARRO, J.D., COLMENERO-FLORES, J.M., KNICKER, H., Catena, 147, 2016, p. 280. 43.MARKS, E.A.N., ALCANIZ, J.M., DOMENE, X., Plant and Soil, 385, no. 1-2, 2014, p. 87.

44.KHAN, W.U., RAMZANI, P.M.A., ANJUM, S., ABBAS, F., IQBAL, M., YASAR, A., IHSAN, M.Z., ANWAR, M.N., BAQAR, M., TAUQEER, H.M., VIRK, Z.A., KHAN, S.A., Chemosphere, 185, 2017, p. 1144.

45.VO, M.H.,WANG, C.H., Compost Science \& Utilization, 23, no. 2 , 2015, p. 117.

46.SMIRNOVA, N., DEMYAN, M.S., RASCHE, F., CADISCH, G., MULLER, T., Open Journal of Soil Science, 4, no. 5, 2014, p. 161.

47.EL-MAHROUKY, M., EL-NAGGAR, A.H., USMAN, A.R., AL-WABEL, M., Pedosphere, 25, no.1, 2015, p. 46.

48.CAVALLI, D., CORTI, M., BARONCHELLI, D., BECHINI, L., MARINO GALLINA, P., Geoderma, 308, 2017, p. 26.

49.LIU, X., ZHENG, J., ZHANG, D., CHENG, K., ZHOU, H., ZHANG, A., LI, L., JOSEPH, S., SMITH, P., CROWLEY, D., KUZYAKOV, Y., PAN, G., Sci Total Environ, 554-555, 2016, p. 259.

50.LIAO, N., LI, Q., ZHANG, W., ZHOU, G., MA, L., MIN, W., YE, J., HOU, Z., European Journal of Soil Biology, 72, 2016, p. 27.

51.MENDEZ, A., GOMEZ, A., PAZ-FERREIRO, J., GASCO, G., Chemosphere, 89, no. 11, 2012, p. 1354.

$\overline{\text { Manuscript received: } 16.07 .2018}$ 